\title{
ブタ腸内におけるカプセル内視鏡用磁気アクチュエータの駆動
}

\section{Moving of a Magnetic Actuator for a Capsule Endoscope in the Intestine of a Pig}

\author{
千葉 淳 $\cdot$ 仙道雅彦・石山和志・荒井賢一 \\ 東北大学電気通信研究所, 仙台市青葉区片平 2-1-1 (广 980-8577)
}

\author{
A. Chiba, M. Sendoh, K. I shiyama, and K. I. Arai \\ Research Institute of Electrical Communication, Tohoku University, 2-1-1 Katahira Aoba-ku Sendai 980-8577, J apan
}

Application of a magnetic actuator to a capsule endoscope is proposed. Capsule-type magnetic actuators were fabricated and their motion properties were investigated in a silicone tube and in the intestine of a pig. The dummy capsule is $11 \mathrm{~mm}$ in diameter and $40 \mathrm{~mm}$ in length. This magnetic actuator is composed of a permanent magnet inside the dummy capsule and spiral structures outside it. The permanent magnet is magnetized in the direction of the diameter. When a rotational magnetic field is applied, the magnetic actuator rotates and moves wirelessly. The velocity of capsules with top spirals was examined in a silicone tube. In addition, a motion test was conducted in the intestine of a pig. The actuator can pass through the small and the large intestines over distances of $450 \mathrm{~mm}$ and $400 \mathrm{~mm}$, respectively, in less than $150 \mathrm{~s}$. The capsule can pass out of the bag-shaped section of the large intestine. This result shows that the actuator has the potential to be used in the guidance system of a capsule endoscope.

Key words: capsule endoscope, magnetic actuator, rotational magnetic field, spiral structure, intestine

$$
1 \text {. はじめに }
$$

近年 ,世界的な高齢化の進行により患者の QOL (Quality Of Life)を向上させるための医療技術, 特に低侵襲診断・ 治療に注目が集まっている，光の中でも，飲み込むだけで 胃や腸などの消化管内を観察できるカプセル内視鏡が注 目されている ${ }^{1)}$.このカプセル内視鏡には, 現在の胃カメ ラや大腸内視鏡での検査のように局所麻酔をかけたり，長 い管を挿入する際の苦痛がなくなるといった利点がある． また ,これまで観察の難しかった小腸内の観察にも大きな 期待が寄せられている.しかし, カプセル内視鏡は推進機 構を持たず,消化管の蠕動運動で受動的に移動するので病 変を見逃してしまう可能性がある.また，推進機構を持た ないことで体内に残留して，人体に影響を与えてしまう可 能性もある.したがって, カプセル内視鏡に何らかの推進 機構を付加することが望まれている .カプセル内視鏡推進 機構の重要な性能として, ワイヤレス駆動と 3 次元方向制 御が挙げられる.磁気アクチュエータは，これらの性能を
満たし , カプセル内視鏡の推進機構としての役割を充分果 たせると考えられる .

我々は先に永久磁石とらせん構造からなるスパイラル 型磁気マイクロマシンを開発し, ワイヤレスで推進方向制 御が可能であることを示した ${ }^{2 / 3)}$ ，光れを基に，磁気アク チュエータによる大腸内視鏡誘導機構が有効であること をイヌの動物実験で示した ${ }^{4)}$. また , カプセル型磁気アク チュエータがシリコーンチューブ内を駆動可能であるこ とを示した ${ }^{5)}$. 本研究では, 先端部分までらせんを巻いた カプセル型磁気アクチュエータの速度特性をシリコーン チューブ内で確認した . また, 生体内て駆動可能であるこ とを確認するため,ブタより摘出した腸内でカプセル型磁 気アクチュエータの動作を確認したので報告する .

\section{2. 素子構成}

カプセル型磁気アクチュエータは内部に永久磁石, 外部 にらせん構造を持つ. 永久磁石は直径方向に着磁してあ り，外部より回転磁界を印加することでカプセルは回転 し,らせん構造により回転を推力に变える(Fig. 1).このと き,らせん形状により発生する推力や推進速度は変化する と考えられる.試作したカプセル型磁気アクチュエータの 概略图をFig. 2 に，写真をFig. 3 に示す.試作したアクチ ユエータのサイズ ( $\varphi 11 \mathrm{~mm} \times 40 \mathrm{~mm}$ ) は現在実用化され ているカプセル内視鏡のサイズ ( $\varphi 11 \mathrm{~mm} \times 26 \mathrm{~mm}$ ) とほ ぼ同サイズとした.らせんとして直径 $1 \mathrm{~mm}$ の丸断面のビ ニール線を用いた。

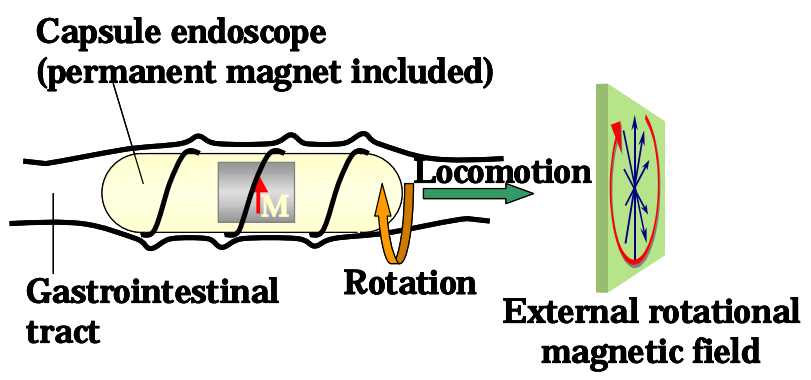

Fig. 1 Conceptual illustration of capsule endoscope-utilized magnetic actuator. 
3 . 先端らせん

\section{1 実験方法}

磁気アクチュエータはらせん構造によって，推進力を発 生する．らせん構造を効果的に利用できれば，推進力を向 上できると考えられる.乥こでカプセルの前方後方にある 球面の部分にまでらせんを巻くことで, 推進力を向上させ ることができると考えた . 先端らせんの構造を持つカプセ ル型磁気アクチュエータの写真を Fig. 4 に示す.同図に示 されるように,先端らせんはらせん構造をカプセルの先端 部分まで伸ばした構造を持つ. 先端部分にらせんを巻いた ことで, 全体のらせん長が長くなり推力の向上が考えら れ，さらに前方が閉じている腸を駆動する際に，腸を広げ て推進できる効果か期待される. 先端らせんによる効果を シリコーンチューブ内で確認した .水位を変えた場合の速 度を測定し, 先端らせんの有無で比較した . 速度測定の実 験系の概略图をFig. 5 に示す .この実験系をFig. 6 に示す 回転磁界発生用 3 軸へルムホルツコイル内に入れ, カプセ ル型磁気アクチュエータの推進速度を測定した .らせん形 状は, らせん角度 $45^{\circ}$, らせん条数 2 のカプセル型磁気 アクチュエータを用いた . 回転磁界周波数は $1 \mathrm{~Hz}$, 回転 磁界強度を $8 \mathrm{kA} / \mathrm{m}$ とした。

\section{2 実験結果}

推進速度の測定結果を Fig. 7 に示す.同图に示されるよ うに，先端らせんを付加することで推進速度が向上してい ることが分かった、推進速度が向上した理由が2つ考えら れる.1つは，推進力を発生させるらせん長さが大きくな り，推進力が向上したこと．もう1つは，先端にらせんを 付加したことで, 前方のチューブを広げる効果か現れて推 進速度が向上したことである．腸内を通過する場合には， 特に後者の効果が大きいと考えられる．すなわち，閉塞部 のようなカプセルの前方が閉じている場所に遭遇した際 に，先端らせんの効果で容易に通過できる場合が出てくる と考えられる . また , 水位が高くなると先端らせんの効果 が小さくなるという結果は, 水圧が先端らせん部分のチュ 一ブを広げる効果を上回っているためと考えられる.以上 の結果から，先端らせんは腸内を推進する際に大きな効果 があると考えられる .

\section{4 ．ブタ腸内での動作}

\section{1 実験方法}

カプセル型磁気アクチュエータの動作をブタの腸内に おいて確認した.内寸 $190 \mathrm{~mm} \times 190 \mathrm{~mm} \times 30 \mathrm{~mm}$ の ケース内を生理食塩水で满たし，この中にブタの腸をピン 止めした . 腸内に試作したカプセル型磁気アクチュエータ を入れ，ケースごと回転磁界発生用 3 軸ヘルムホルツコイ ル内に入れ動作を確認した . 3軸ヘルムホルツコイルは，

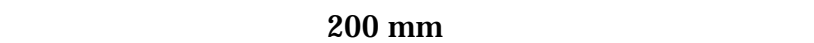

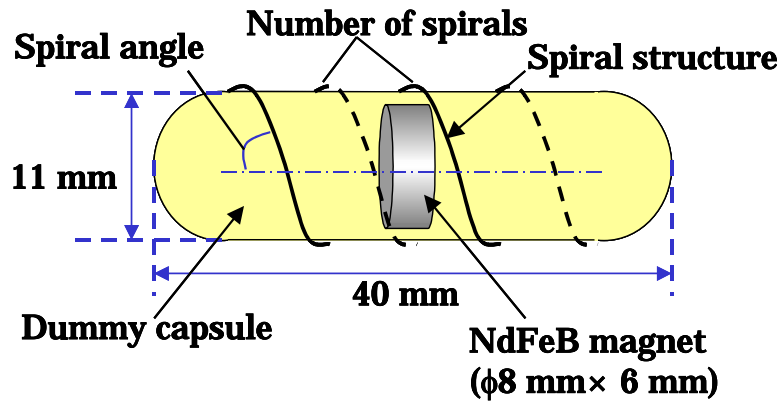

Fig. 2 Schematic view of a capsule-type magnetic actuator.

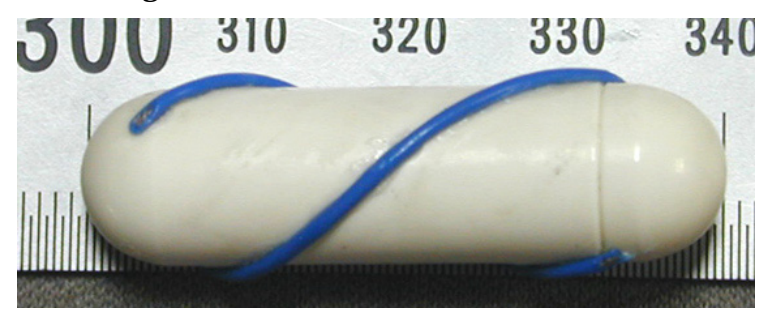

Fig. 3 Photograph of a capsule-type magnetic actuator.

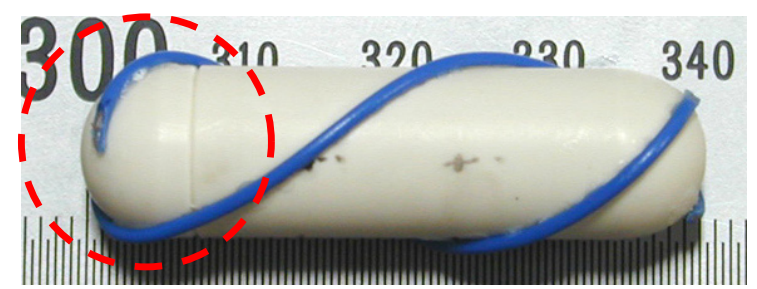

a) Side view

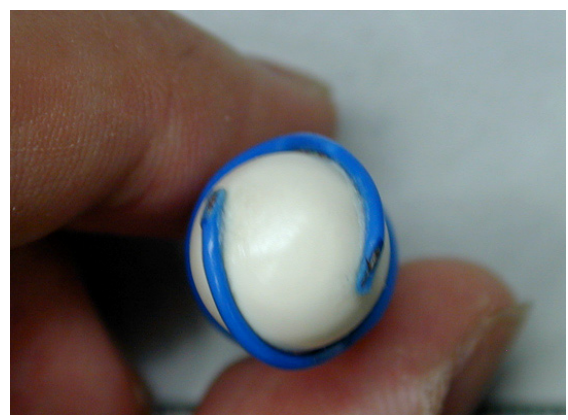

b) Top view

Fig. 4 Photograph of a capsule-type magnetic actuator (with top spirals).

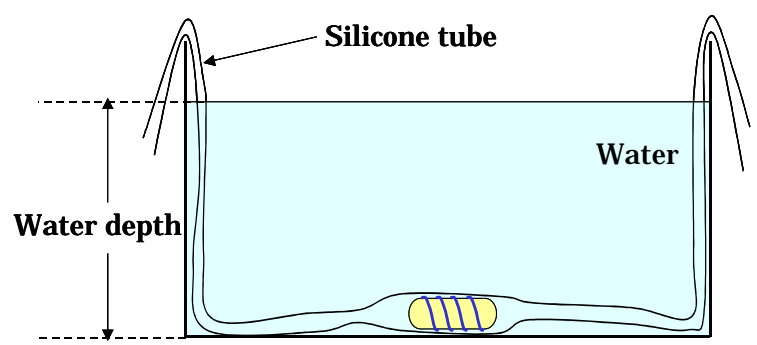

Fig. 5 Schematic view of velocity measurement. 
を用いて，回転磁界の回転面及び回転方向を任意にかつ 3 次元的に制御できる. 回転磁界周波数は $1 \mathrm{~Hz}$, 回転磁界 強度を $8 \mathrm{kA} / \mathrm{m}$ とした .らせん形状はらせん角度 $45^{\circ}$, ら せん条数 4 を用いた .

\section{2 小腸での動作}

小腸での実験結果をFig. 8 に示す.実験で使用したブタ 小腸の内径はカプセル型磁気アクチュエータの外径と同 程度である.図中白実線で囲まれた部分に磁気アクチュエ 一タがある.破線は推進経路を示している.実験の結果， 腸の形状を変えることなく約 $450 \mathrm{~mm}$ 先の目的地まで 2 分 30 秒て到達することを確認した . また, 湾曲部分では 曲率半径約 $30 \mathrm{~mm}$ の湾曲部も通過できることが示され た .アクチュエータの動作もスムーズであり，回転磁界に よる方向制御で目的地まで問題なく推進できる事が確認 できた.以上の結果から，らせん構造をもつ磁気アクチュ エータが管径の大きさが同程度の腸内において, 推進可能 であることが示された .

\section{3 大腸での動作}

大腸での実験結果をFig. 9 に示す .図中白実線で囲まれ た部分に磁気アクチュエータがあり，破線は推進経路を示 している . 同图から分かるように , 大腸の管径は最大で小 腸の 2〜3 倍の大きさである . また , 大腸にはハウストラ と呼ばれる袋状の構造があるためカプセルが袋部分に入 り込みやすく，推進しにくい形状になっている(Fig. 10-(a)) . 袋状構造の大きさは大小樣々であり，すべての袋 部分に入り込まず深部まで推進することは難しいと考え られる.すなわち, 袋状構造から脱出できることがカプセ ル内視鏡の推進において重要であると考えられる.本アク チュエータは目的地までの約 $400 \mathrm{~mm}$ を 2 分 30 秒て到達 することができた .この推進時間は, 袋状構造を脱出する 時間も含まれており，大腸内視鏡検査の深部までの到達時 間と比較しても同程度の到達時間で,十分な推進速度であ ると考えられる . また , 外部から印加する回転磁界の周波 数を $0.1 \mathrm{~Hz}$ 程度まで低くしつつ回転磁界面を変化させる ことで, カプセル型磁気アクチュエータが袋状構造から脱 出できる事が確認できた .これは回転磁界の周波数を低く することでカプセルは進まず, 弚の場所で旋回することが でき，推進方向を探すことができるためである(Fig. 10-(b) , (c)) . 以上の結果から , カプセル型磁気アクチュエ 一タが腸内を推進できることが確認できた、推進時間も十 分であり，回転磁界面の変化による方向転換も有効である ことが分かった . 腸特有の袋状の構造にも方向転換で対応 でき,カプセル型磁気アクチュエータが非常に有効である ことが確認できた

\section{5 . まとめ}

永久磁石とらせん構造からなる磁気アクチュエータの カプセル内視鏡への応用を目的として, 試作したカプセル 型磁気アクチュエータの動作をシリコーンチューブ及び

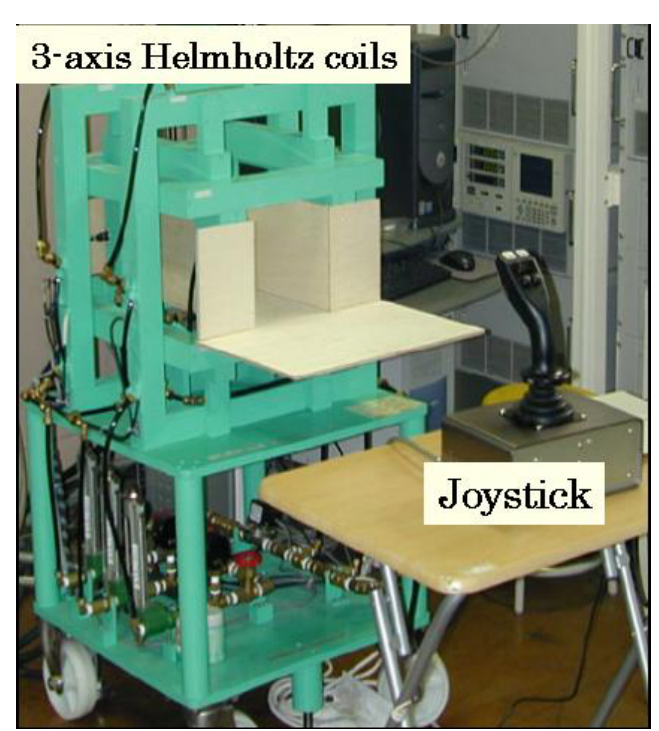

Fig. 6 Photograph of the three-dimensional rotational magnetic field supply system.

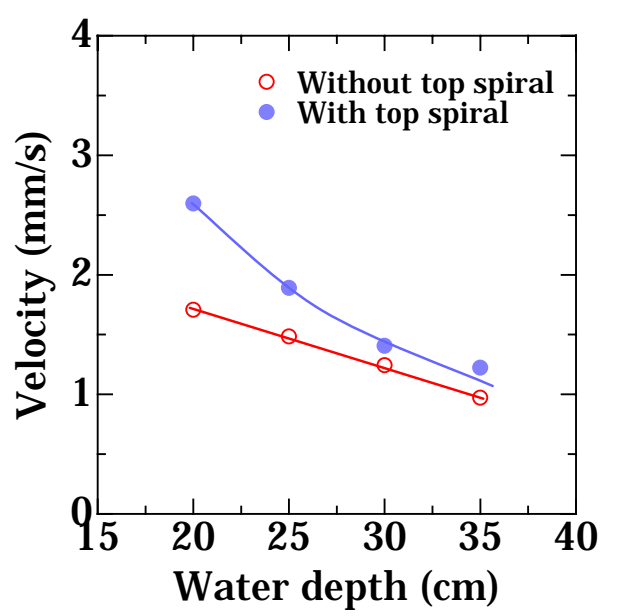

Fig. 7 Relationship between the velocity and water depth.

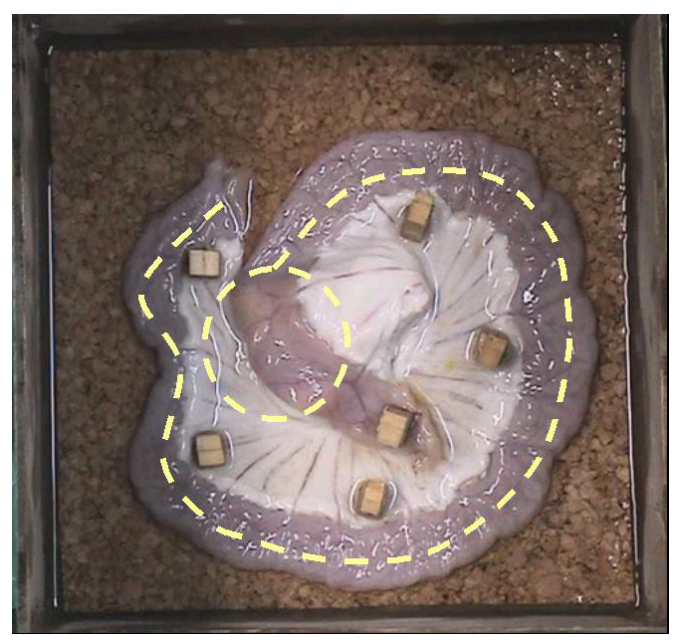

Fig. 8 Photograph of an experimental result (small intestine). 


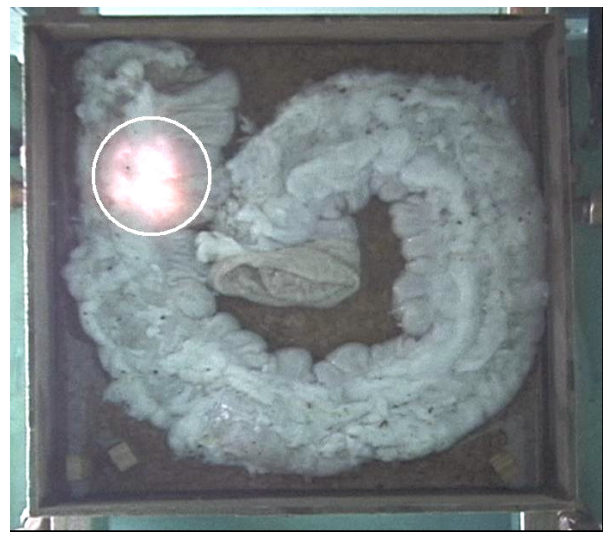

a) $0 \mathrm{~s}$

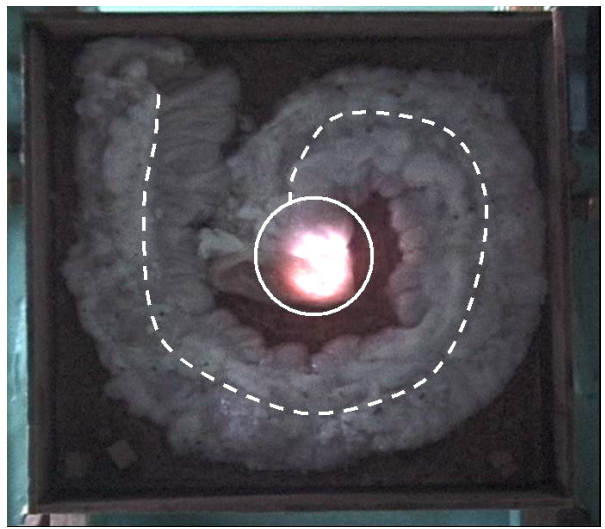

b) $210 \mathrm{~s}$

Fig. 9 Photograph of an experimental result (large intestine).

ブタ腸内において確認した .この結果 , 本アクチュエータ がブタ腸内においてワイヤレスで駆動可能であることが 示された . また, 先端らせんによる推進力増加や回転磁界 面を変化させることでの方向転換も有効であることが確 認できた . 以上の結果は, 本アクチュエータがカプセル内 視鏡の推進機構として有用であることを示している .

今後の検討としては, 今回の結果より平面配置した腸で の動作確認はできたので, 立体的に配置した腸での確認も 必要である.また, 磁気アクチュエータの推進力向上が重 要であるので, 弚のためには, らせん形状の最適化などを 検討する必要がある.更に, カプセル型磁気アクチュエー タの動作を動物実験等で確認することも検討したい．ー 方，小型化についても検討が必要である . 小型化は, 患者 への苦痛を軽減できるような利点がある．また，更に小型 化することで腸だけではなく，血管などの細い管腔への応 用の可能性が広がってくる. しかし, 更なるカプセル内視 鏡の小型化は, 全体のらせん長さが減少することによる推

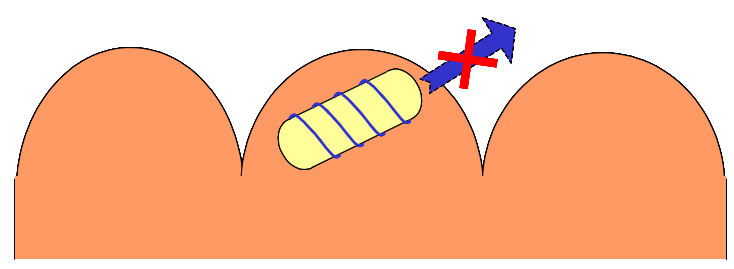

a) Dead end

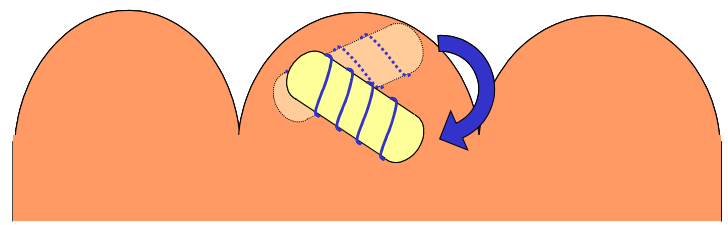

b) Turn

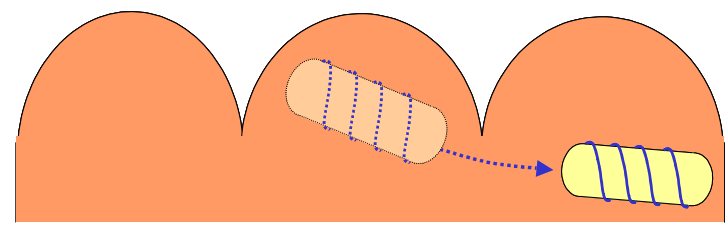

c) Passage out of the bag-shaped section of the large intestine

Fig. 10 Schematic view of the method of passage through the large intestine.

力低下等の問題が出てくるため, 今後の検討が必要であ る。

\section{References}

1). G. Iddan, G. Meron, A. Glukhovsky, P. Swain: Nature, 405, 417 (2000)

2). T. Honda, K. I. Arai, and K. Ishiyama: IEEE Trans. Magn., 32, 5085 (1996).

3). M. Sendoh, A. Yamazaki, K. Ishiyama, K. I. Arai, and M. Inoue: Trans. IEE of J apan, 120-A, 301 (2000-3).

4). A. Chiba, M. Sendoh, K. Ishiyama, Y. Suda, K. I. Arai, T. Komaru and K. Shirato: J. Magn. Soc. J pn., 28, 433 (2004).

5). M. Sendoh, K. Ishiyama, and K. I. Arai: IEEE. Trans. Magn., 39, 3232 (2003).

2004 年 10 月 6 日受理, 2005 年 1 月 14 日採録 